\title{
ANALYSIS OF HEAVY METALS (LEAD AND CADMIUM) CONTAINED ON THE ILLUSTRATED CERAMIC PLATE BY ATOMIC ABSORPTION SPECTROPHOTOMETER
}

\author{
RESMI MUSTARICHIE*, WIWIEK INDRIYATI, RIAJAWAN RIOKOGRO
}

Department of Pharmaceutical Analysis and Medicinal Chemistry, Faculty of Pharmacy, Universitas Padjadjaran, Indonesia. Email: resmi.mustarichie@unpad.ac.id

Received: 20 March 2017, Revised and Accepted: 26 April 2017

\section{ABSTRACT}

Objective: This study aims to determine whether there are lead $(\mathrm{Pb})$ and cadmium $(\mathrm{Cd})$ metals caused by the dilution of color on a locally illustrated plate.

Methods: Illustrated ceramic plates soaked for $1 / 2,1$, and 2 hrs in acidic solution were then measured using atomic absorption spectrophotometer to the availability of $\mathrm{Pb}$ and $\mathrm{Cd}$.

Results: The results showed that in the three samples of locally made illustrated ceramic plates gave contamination of $\mathrm{Pb}$ and $\mathrm{Cd}$. The highest $\mathrm{Pb}$ content of metal contamination at the time of $1 / 2 \mathrm{hr}$ immersion in the sample plate of the brand B was equal to 1.2539 ppm. At the time of $1 \mathrm{hr}$ immersion in the sample plate of the brand, $\mathrm{C}$ was equal to $0.7737 \mathrm{ppm}$. The highest Cd content of metal contamination at the time of $1 / 2 \mathrm{hr}$ immersion in the sample plate of the brand B was 0.2690 .

Conclusion: The results of this study indicated that the locally made illustrated plate could cause pollution of Pb and Cd. These results suggested caution in the use of decorated ceramic plates, especially, for acidic foods and the need for further research for various brands of ceramic plates display in the market.

Keywords: Illustrated plate, Acidic food, Lead, Cadmium, Heavy metal contamination, Atomic absorption spectrophotometer.

(C) 2017 The Authors. Published by Innovare Academic Sciences Pvt Ltd. This is an open access article under the CC BY license (http://creativecommons. org/licenses/by/4. 0/) DOI: http://dx.doi.org/10.22159/ajpcr.2017.v10i8.18591

\section{INTRODUCTION}

Discoloration on the paint that coats the surface of the plate can occur due to acidic fluid from food, so it is necessary to know the extent to which this discoloration occurs. Paint generally uses basic ingredients that contain heavy metals such as lead $(\mathrm{Pb})$ and cadmium (Cd) [1-3]. Paint containing $\mathrm{Pb}$ carbonate (white) and $\mathrm{Pb}$ oxide (red) as much as $5-40 \%$. The American Standards Association in 1955 determined that the cat toys, home furnishings, and interior residence must not contain more than $1 \% \mathrm{~Pb}$. Groceries said not contaminated by $\mathrm{Cd}$ when it contains $<0.05 \mu \mathrm{g}$ per gram wet weight, and the average intake per day is approximately $50 \mu \mathrm{g}$ [4]. The food samples such as maize, sorghum, soybeans, beans, millet, fennel, and herbal materials have been reported and contaminated by heavy metals [5-7].

Known hazardous heavy metals because it has a high density and some small concentrations can be toxic and dangerous. Harmful heavy metals into the system due to bioaccumulation meaning the amount of heavy metal that accumulates faster than the amount excreted and degraded [8-10]. Various heavy metals are toxic enzymes and toxins capillaries. Its toxic effects are not only based on a reaction mechanism but also will have the effect of work, and its role is unknown [11-13]. Cd and $\mathrm{Pb}$ studies using atomic absorption spectrophotometry (AAS) have been known since long ago $[5,14]$.

This study aims to determine whether there is any metal contamination of $\mathrm{Pb}$ and $\mathrm{Cd}$ due to discoloration pictorial plates, as well as measuring the levels of each of the heavy metal by the method of AAS. The results of this study are expected to provide information about the contamination of heavy metals, especially, $\mathrm{Pb}$ and $\mathrm{Cd}$ in the discoloration pictorial plates as well as information regarding safety in use.

\section{EQUIPMENT, MATERIAL, AND METHODS}

Equipment

AAS AA-6501 S (Shimadzu).

\section{Methods}

The method used was modified from Adarna and Castañares [15], Villar et. al. [16], and Ewing [17] as well as following Manuals of AA6501S Shimadzu.

Method sampling was done randomly from a dozen locally pictorial ceramic plate. Taken three kinds of samples of graphic plates with different brands. Each sample was soaked with $40 \mathrm{~mL}$ of vinegar and cook for $1 / 2 \mathrm{hr}, 1 \mathrm{hr}$, and $2 \mathrm{hrs}$. Taken each $5 \mathrm{~mL}$ and was added to the vial. Assay of $\mathrm{Pb}$ and $\mathrm{Cd}$ using AAS. The method was optimized based on the proper atomic lines for $\mathrm{Pb}(283.306 \mathrm{~nm})$ and $\mathrm{Cd}(228.802 \mathrm{~nm})$. The standard solutions (1000 mg/L Pb and $1000 \mathrm{mg} / \mathrm{L} \mathrm{Cd}$ ) available from Shimadzu Corporation. AAS was connected to a voltage source and a stabilizer. Floppy drive inserted, and monitor power was turned on. Air blowers and gas included. Fuel gas was opened with a pressure of $0.9 \mathrm{kgf} / \mathrm{cm}^{2}$. Making the standard curve using standard solution. Sample absorbance was measured and plotted on a standard curve so that the concentration of the sample was then able to be calculated.

\section{RESULTS AND DISCUSSION}

Standard curve

A standard curve for each metal was examined based on the results measuring the absorbance of the standard solution of each metal with a broad range of concentrations. Standard curve to metallic $\mathrm{Pb}$ and $\mathrm{Cd}$ was set at 2, 4, 6, and $8 \mathrm{ppm}$ and $8,10,12$, and $14 \mathrm{ppm}$, respectively. Statistical software SPSS Version 10.0 was used for data analysis. The results of the calculation of the linear regression equation give correlation coefficient $(\mathrm{r})$ 0.999-0.999 for the $\mathrm{Pb}$ and Cd metals. 
Correlation coefficient approaching a value of 1 indicated that the line forms a nearly ideal linear relationship so that it can be used as a reference in determining the levels of metal contamination in the sample. A linear relationship is achieved if the value $b=0$ and $r=+1$ or -1 depending on the direction of the line. The value of a showed sensitivity analysis of the instrument used [18].

\section{Levels of metals in samples}

From the standard curve, the concentration of each metal can be used to calculate the concentration of each metal in the sample. The results of the assay of metal contamination in the sample display ceramic plates are as follows (Tables 1 and 2, Figs. 1 and 2).

This study showed that the samples analyzed pictorial ceramic plates contained metal contamination of $\mathrm{Pb}$ and $\mathrm{Cd}$ in varying concentrations. The big difference in the average metal content of $\mathrm{Pb}$ in samples per hour could be due to the speed and magnitude of the corrosion process, the process of printing images, and soaking time. In sample A, B and C contained elevated levels of $\mathrm{Pb}$ metal contamination at the date of immersion from $1 / 2 \mathrm{hr}$ to $2 \mathrm{hrs}$; this was due to the solubility of $\mathrm{Pb}$ ions from the corrosion process.

From the research of metal $\mathrm{Cd}$, contamination in the sample pictorial ceramic plates contained elevated levels every hour to samples A, B, or C. This could be caused by Cd ion solubility of the paint on the plate for a metal readily soluble in acidic conditions increases, in this case, $25 \%$ cooking vinegar was applied. In the sample A, metal Cd little experience corrosion process with vinegar cooked $25 \%$, so AAS does not detect it with flame AA-6501 S, this could be caused by the process of printing images on a sample of a higher quality than the sample B or sample C.

Comparison of other similar results was not able to be carried out as no other related article found. Research on analysis of $\mathrm{Pb}$ and $\mathrm{Cd}$ was mostly done in other areas, such as on plants including Ipomoea

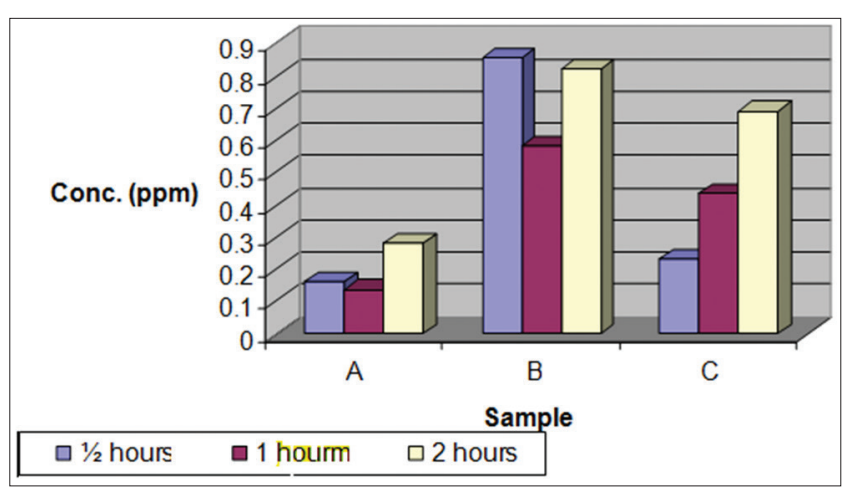

Fig. 1: Levels of lead in the ceramic sample

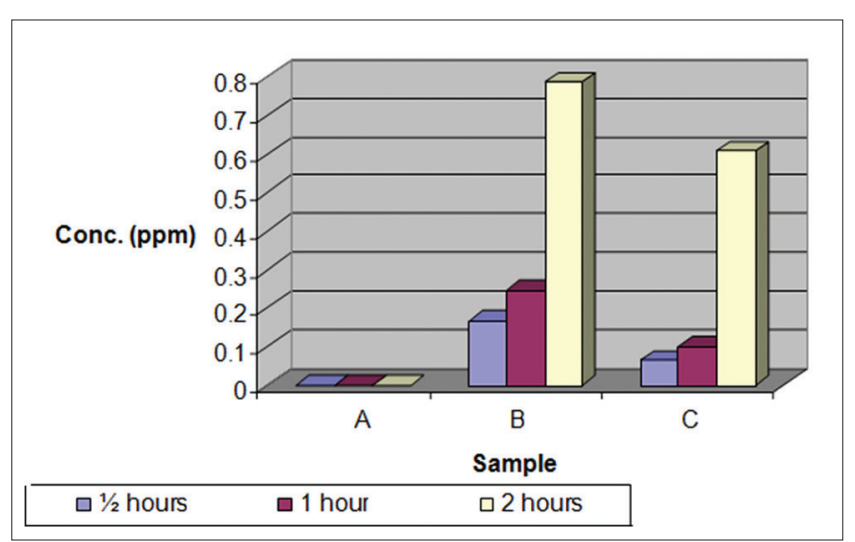

Fig. 2: Levels of cadmium in the ceramic sample aquatica [19,20], Jali, Coix lacryma [21], Green mustard, Brassica rapa and carrot, Daucus carota [22], Seagrasses, Enhalus acoroides [23], and on Crops Apu-Apu, Pistia stratiotes L. [24].

\section{Statistical data analysis}

The outcome levels of heavy metals on the ceramic plate picture obtained from the assay using AAS with flame AA-6501 S and performed statistical analysis using factorial experimental design in the General Linear Methods with SPSS statistical software version 11.5 by a factor of brand plates and time. Here is a Table 3 of variance analysis results on samples of ceramic plates display.

In statistical testing, Pb levels of the brand plate using ANOVA and the degree of confidence of $95 \%$ obtained a significant level of 0.462 . By taking the value of $\alpha=0.05$, then the value of significance for $0.462>\alpha=0.05$, which led to $\mathrm{H} 0$, which meant that the researcher had 95\% confidence that there were no differences in the levels of real metallic $\mathrm{Pb}$ from each brand plate. The result said that the brand plates $\mathrm{A}, \mathrm{B}$, and $\mathrm{C}$ had the same relative levels of $\mathrm{Pb}$. If follow-up testing was done with Duncan's test, it would be known that Brand A had different levels with brand $\mathrm{B}$ because they were in different groups. While the brand $\mathrm{A}$ there were no real differences in $\mathrm{Pb}$ levels with brand $\mathrm{C}$, meaning that the degree of $\mathrm{Pb}$ for the brand $\mathrm{A}$ was almost equal to $\mathrm{C}$, because of brand $\mathrm{A}$ and brand $\mathrm{C}$ were in the same group. At the brand, there were no real differences in $\mathrm{Pb}$ levels with brand $\mathrm{C}$, meaning that the $\mathrm{Pb}$ standards for the brand $\mathrm{B}$ almost the same as brand $\mathrm{C}$, for brands $\mathrm{B}$ and $\mathrm{C}$ names were in the same group. Table 4 shows highest metal content in sample $\mathrm{B}$, followed by the sample $\mathrm{C}$ and the smallest amounts of $\mathrm{Pb}$ in sample $\mathrm{A}$.

Statistically, $\mathrm{Pb}$ levels against dipping time, at the degree of confidence of $95 \%$ obtained a significant level of 0.035 . By taking the value of $\alpha=0.05$, then the significance value of $0.035<\alpha=0.05$, which led to $\mathrm{H} 0$, was rejected. Therefore, researchers had $95 \%$ confidence that there were

Table 1: Results of determination of levels of lead in illustrated ceramic samples (ppm)

\begin{tabular}{|c|c|c|c|c|}
\hline \multirow[t]{2}{*}{ Sample } & \multicolumn{4}{|c|}{ Hour } \\
\hline & n & $1 / 2$ & 1 & 2 \\
\hline \multirow[t]{2}{*}{ A } & 1 & 0.1131 & 0.0062 & 0.2201 \\
\hline & 2 & 0.2110 & 0.2722 & 0.3480 \\
\hline Mean & & 0.1620 & 0.1392 & 0.2840 \\
\hline \multirow[t]{2}{*}{ B } & 1 & 0.4596 & 0.5015 & 0.5077 \\
\hline & 2 & 1.2539 & 0.6667 & 1.1316 \\
\hline Mean & & 0.8567 & 0.5841 & 0.8196 \\
\hline \multirow[t]{2}{*}{ C } & 1 & 0.3639 & 0.7737 & 0.6239 \\
\hline & 2 & 0.1009 & 0.0978 & 0.7615 \\
\hline Mean & & 0.2324 & 0.4375 & 0.6927 \\
\hline
\end{tabular}

A: Illustrated ceramic sample brand A, B: Illustrated ceramic sample brand B

C: Illustrated ceramic sample brand $C$

Table 2: Results of determination of levels of cadmium in illustrated ceramic samples (ppm)

\begin{tabular}{|c|c|c|c|c|}
\hline \multirow[t]{2}{*}{ Sample } & \multicolumn{4}{|c|}{ Hour } \\
\hline & $\mathbf{n}$ & $1 / 2$ & 1 & 2 \\
\hline \multirow[t]{2}{*}{$A$} & 1 & ND & ND & ND \\
\hline & 2 & ND & ND & ND \\
\hline Mean & & ND & ND & ND \\
\hline \multirow[t]{2}{*}{ B } & 1 & 0.2690 & 0.2906 & 0.8080 \\
\hline & 2 & 0.0676 & 0.2034 & 0.7661 \\
\hline Mean & & 0.1683 & 0.2470 & 0.7870 \\
\hline \multirow[t]{2}{*}{$\mathrm{C}$} & 1 & 0.0643 & 0.0997 & 0.6479 \\
\hline & 2 & 0.0643 & 0.0997 & 0.5677 \\
\hline Mean & & 0.0643 & 0.0997 & 0.6078 \\
\hline
\end{tabular}

ND: Not detected, A: Illustrated ceramic sample brand A, B: Illustrated ceramic sample brand B, C: Illustrated ceramic sample brand C 
different levels of metallic Pb real at the time of immersion $1 / 2 \mathrm{hr}, 1 \mathrm{hr}$, and $2 \mathrm{hrs}$. This meant that at the time of immersion $1 / 2 \mathrm{hr}, 1 \mathrm{hr}$ and $2 \mathrm{hrs}$ have $\mathrm{Pb}$ levels were not the same. If follow-up testing was done with Duncan's test, it would be known that at the time of immersion $1 / 2 \mathrm{hr}, 1 \mathrm{hr}$, and $2 \mathrm{hrs}$ and there were no real differences in $\mathrm{Pb}$ levels because they were in the same group. From the results of a further test was seen that the soaking time $2 \mathrm{hrs}$ had the highest standards of $\mathrm{Pb}$ metal (Table 5).

The interaction between Plate Brands against dipping time by using ANOVA, obtained the value of the significant level of 0.775 . By taking the value of $\alpha=0.05$, then the critical value of $0.775>\alpha=0.05$, which led to $\mathrm{H} 0$, therefore researchers had $95 \%$ confidence that there were no real differences in $\mathrm{Pb}$ levels due to the interaction between the brand plate with immersion time, meant soaking time did not affect the metal content of $\mathrm{Pb}$ in each brand plate.

Statistical methods for the $\mathrm{Pb}$ were also applied to the determination of $\mathrm{Cd}$. It was found that there were different levels of real metal $\mathrm{Cd}$ from each brand plate. This meant that the brand plates $\mathrm{A}, \mathrm{B}$, and $\mathrm{C}$ had a metal content were not the same. By applying Duncan's test, it found that the three brands of these plates had different levels. From the results, this trial was seen that brand B had higher levels of the metal Cd was the highest, while the smallest standards of Cd metals contained in the brand $\mathrm{A}$.

The significant level of 0.000 was found for Cd levels against dipping time. By taking the value of $\alpha=0.05$, then the significance value $0.000<\alpha=0.05$, which led to $\mathrm{H} 0$, was rejected. Therefore, there were different levels of real Cd metal at the time of immersion $1 / 2 \mathrm{hr}, 1 \mathrm{hr}$, and 2 hrs. By Duncan's test, it found that at the time of immersion $1 / 2 \mathrm{hr}$ and $1 \mathrm{hr}$, there was no real difference because they were in the same group. As for the 2-hr soaking time had different levels with time soaking $1 / 2 \mathrm{hr}$ and 1 $\mathrm{hr}$ of being in different groups. It was found that at the date of immersion $2 \mathrm{hrs}$ had the highest levels of the metal Cd.

The interaction between brand dishes against dipping time using ANOVA found that there were real differences in levels of $\mathrm{Cd}$ because

Table 3: List of ANOVA for lead against metal assay brand plates and time

\begin{tabular}{lllll}
\hline Sources of variation & $\mathbf{d b}$ & $\mathbf{J K}$ & $\mathbf{K T}$ & $\mathbf{P}$ \\
\hline Mean & 1 & 3.932423 & 3.932423 & \\
Time & 2 & 0.158211 & 0.079106 & 0.462 \\
Plate brands & 2 & 0.937143 & 0.468571 & 0.035 \\
Time*Brands & 4 & 0.166347 & 0.041587 & 0.775 \\
Mistake & 9 & 0.844587 & 0.093839 & \\
Total & 18 & 6.038672 & & \\
\hline
\end{tabular}

Table 4: Duncan's test results continue to lead levels of brand plates

\begin{tabular}{llll}
\hline Sample & n & Group 1 & Group 2 \\
\hline A & 6 & 0.1951 & \\
C & 6 & 0.4536 & 0.4536 \\
B & 6 & & 0.7535 \\
Sig. & & 0.178 & 0.124 \\
\hline$\alpha=0.05$ & & &
\end{tabular}

Table 5: Test results continue Duncan's lead levels against immersion time

\begin{tabular}{lll}
\hline Time & n & Group 1 \\
\hline 1 & 6 & 0.3864 \\
$1 / 2$ & 6 & 0.4171 \\
2 & 6 & 0.5988 \\
Sig. & & 0.280 \\
\hline$\alpha=0.05$ & &
\end{tabular}

of the interaction between the brand plate with soaking time, meant soaking affected the metal content of $\mathrm{Cd}$ in each brand plate.

\section{CONCLUSIONS}

The results of this study indicated that the locally made illustrated plate could cause contamination of $\mathrm{Pb}$ and $\mathrm{Cd}$. These results suggested caution in the use of illustrated ceramic plates, especially, for acidic foods and the need for further research for various brands of illustrated ceramic plates in the market. Furthermore, it can be suggested further study on the rate of accumulation of heavy metals in the blood or biological fluid after eating foods that use pictorial ceramic plates.

\section{REFERENCES}

1. Verbiest P. Lead and Cadmium in Paints Pose Threat to Health; 2012. Available from: http://www.renewableenergyworld.com/articles/print/ special-supplement-wind-technology/volume-2/issue-1/wind-power/ lead-and-cadmium-in-paints-pose-threat-to-health.html. [Last accessed on 2016 Mar 13].

2. Anonim. Available from: http://www.noteaccess.com/MATERIALS/ ToxicityPigmt.htm. [Last accessed on 2016 Mar 13].

3. Anonim. Toxicity of Paint Pigments. Available from: http://www. captainpackrat.com/furry/toxicity.htm. [Last accessed on 2016 Mar 13].

4. Ganiswarna S. Pharmacology and Therapy (Farmakologi dan Terapi). IV $^{\text {th }}$ ed. Jakarta: Bagian Farmakologi Fakultas Kedokteran Universitas Indonesia; 1995. p. 271-88, 800-10.

5. Wyasu G, Onoja E, Omeiza FS. Comparative analysis of the level of lead and cadmium contamination of food during processing with atlas machine and a local grinding stone. Arch Appl Sci Res 2010;2(5):331-6.

6. Garg C, Khan SA, Ansari SH, Garg M. Efficacy and safety studies of Foeniculum vulgare through evaluation of toxicological and standardization parameters. Int J Pharm Pharm Sci 2010;2(2):43-5.

7. Prakash NK, Deepa S, Sripriya N, Bhuvaneswari S. Quality assessment for the presence of heavy metals in herbal materials from the markets of Chennai, India. Int J Pharm Pharm Sci 2014;6(8):574-8.

8. Filov UA. Harmful Chemical Substances. Vol. 1. New York: Ellis Harwood; 1993. p. 555.

9. Jaishankar M, Tseten T, Anbalagan N, Mathew BB, Beeregowda KN. Toxicity, mechanism and health effects of some heavy metals. Interdiscip Toxicol 2014;7(2):60-72.

10. Efsa (European Food Safety Authority). Metals as Contaminants in Food; 2015. Available from: https://www.efsa.europa.eu/en/topics/ topic/metals-contaminants-food. [Last accessed on 2016 Apr 04].

11. Landrigan PJ, Schechter CB, Lipton JM, Fahs MC, Schwartz J. Environmental pollutants and disease in American children: Estimates of morbidity, mortality, and costs for lead poisoning, asthma, cancer, and developmental disabilities. Environ Health Perspect 2002;110(7):721-8.

12. Alissa EM, Ferns GA. Heavy metal poisoning and cardiovascular disease. J Toxicol 2011;2011:21.

13. Sharma B, Singh S, Siddiqi NJ. Biomedical implications of heavy metals induced imbalances in redox systems. Biomed Res Int 2014;2014:26.

14. Lau OW, Li KL. The determination of lead and cadmium in paint by atomic-absorption spectrophotometry utilizing the delves microsampling technique. Analyst 1975;100:430-7.

15. Adarna LN, Castañares JM. Copper, lead and zinc contamination. In: Sediments of Butanone River, Cebu, Philippines, Book of Abstracts of $30^{\text {th }}$ Philippine Chemistry Congress. ASEAN Chemistry in Resonance. Ateneo de Davao University, April, 15-17; 2015. p. 60.

16. Villar C, Stripeikis J, Colautti D, D’Huicque L, Tudino M, Bonetto C, et al. Metals contents in two fishes of different feeding behavior in the lower Parana river and Rio de la Plata estuary. Hydrobiologia 2001;457:225-33.

17. Ewing GW. Instrumental Method of Chemical Analysis. New York: Kogakusha, McGraw-Hill, ltd.; 1969. p. 58, 69-70.

18. Ibrahim S. Statistical and validation and its application. Prosiding Temu Ilmiah Nasional Bidang Farmasi Jurusan Fammasi ITB. Vol. I. Bandung: School of Pharmacy, ITB; 1997.

19. Puspita AD, Melannisa R, Suhendi A. Determination of $\mathrm{Pb}$ and $\mathrm{Cd}$ in sediment and Ipomoea aquatic in surrounding of Bengawan solo river in industrial area of Karanganyar. Pharmacon 2010;11(2):39-42.

20. Mulyani S, Train IG, Sujana A. Identification metal contamination $\mathrm{Pb}$ and $\mathrm{Cd}$ in kale (Ipomoea aquatic) planted in the area of city of Denpasar. J Bumi Lestari 2012;12(2):345-9.

21. Irawanto R, Damayanti A, Tangahu BV, Purwanti IF. Concentration of heavy metals $(\mathrm{Pb}$ and $\mathrm{Cd})$ section aquatic plants Coix lacryma-jobi 
(jali). In: National Seminar on Conservation and Utilization of Natural Resources; 2015. p. 138-46.

22. Priandoko DC, Parwanayoni NM, Sundra IK. Content of heavy metal ( $\mathrm{Pb}$ and $\mathrm{Cd}$ ) on green mustard (Brassica few l. Subsp. Perviridis bailey) and carrot (Daucus Carrota L. Var. Sativa Hoffm) outstanding in the market city Denpasar. J Symbiosis 2013;1(1):9-20.

23. Pratiwi AR, Willian N, Promo A. Analysis of Heavy Metal Content $(\mathrm{Pb})$ and $(\mathrm{Cd})$ to Seagrasses (Enhalus acoroides) as a Bio Indicator Waters in Tanjung Pinang. Available from: http://www.ojs.umrah.ac.id/index. $\mathrm{php} / \mathrm{zarah} / \mathrm{article} /$ download/23/22. [Last accessed on 2016 Mar 24].

24. Raras DP, Yusuf D, Alimuddin A. Content Analysis of Heavy Metal Ion ( $\mathrm{Fe}, \mathrm{Cd}, \mathrm{Cu}$, and $\mathrm{Pb}$ ) in Crops Apu-Apu (Pistia stratiotes $\mathrm{L}$ ) Using Time Variation. Samarinda, Indonesia: Prosiding Seminar Tugas Akhir FMIPA UNMUL; 2015. p. 76-9. 